\title{
The Criminal Defendant's Sixth Amendment Right to Lay Representation
}

Consider a defendant on trial for tax fraud, a criminal offense. $\mathrm{He}$ is wary of court-appointed public defenders, and he cannot afford to hire an attorney he trusts. He knows that he has the right to represent himself, ${ }^{1}$ but because he is a very poor speaker, he moves instead to have his accountant, whom he trusts and who is familiar with both the tax laws and his case, represent him. The defendant's motion raises important questions about the scope of the defendant's right to control the defense he presents to the jury.

Over the last fifty years, the Supreme Court has firmly established that the sixth amendment's guarantee of the right to the "Assistance of Counsel"2 gives a criminal defendant the right to a qualified attorney to aid in his defense. ${ }^{3}$ In Faretta v. California, ${ }^{4}$ however, the Court held that a defendant also has a constitutional right to dispense with the help of counsel and instead conduct his own defense. ${ }^{5}$ This right is not an extension of the right to waive assistance of counsel but is instead an independent right founded on both the structure and history of the sixth amendment. ${ }^{6}$ The sixth amendment right to proceed pro se is designed "to affirm the dignity and autonomy of the accused and to allow the presentation of what may . . . be the accused's best possible defense."

${ }^{1}$ See Faretta v. California, 422 U.S. 806 (1975); infra notes 35-62 and accompanying text.

2 U.S. Const. amend. VI.

3 See, e.g., Powell v. Alabama, 287 U.S. 45, 68-69 (1932) ("The right to be heard would be . . . of little avail if it did not comprehend the right to be heard by counsel."); Johnson v. Zerbst, 304 U.S. 458, 463 (1938) (sixth amendment prevents federal courts in criminal proceedings from depriving the defendant of life or liberty unless the defendant has or waives the assistance of counsel); Gideon v. Wainwright, 372 U.S. 335, 344 (1963) ("[A]ny person haled into court, who is too poor to hire a lawyer, cannot be assured a fair trial unless counsel is provided for him."); Argersinger v. Hamlin, 407 U.S. 25, 37 (1972) (punishment of imprisonment may not be imposed on any defendant who is denied the right to appointed counsel); Scott v. Illinois, 440 U.S. 367, 373-74 (1979) (actual imprisonment is the line defining the constitutional right to appointment of counsel; fines or mere threat of imprisonment do not warrant appointed counsel).

422 U.S. 806 (1975).

- Id. at 836; see infra notes 35-62 and accompanying text (discussing Faretta).

- 422 U.S. at 819 n.15; see infra notes $41-42$ and accompanying text.

7 McKaskle v. Wiggins, 104 S. Ct. 944, 950 (1984). 
The Supreme Court has yet to decide whether a defendant's right to control his defense includes the right to have a lay representative perform the functions the lay defendant himself has a right to perform under Faretta. Though several lower federal courts have addressed the issue, ${ }^{8}$ none has recognized a constitutional right to lay representation. Most have adopted a per se rule prohibiting the use of non-licensed counsel, ${ }^{9}$ and in only two decisions, United States v. Whitese ${ }^{10}$ and United States v. Stockheimer, ${ }^{11}$ have courts concluded that there are circumstances in

3 See, e.g., United States v. Thibodeaux, No. 84-1869, slip op. at 3 (7th Cir. Feb. 20, 1985) (per curiam); Herrera-Venegas v. Sanchez-Rivera, 681 F.2d 41, 42 (1st Cir. 1982); United States v. Wilhelm, 570 F.2d 461, 464-67 (3d Cir. 1978); United States v. Taylor, 569 F.2d 448, 450-51 (7th Cir.), cert. denied, 435 U.S. 952 (1978); United States v. Irwin, 561 F.2d 198, 200 (10th Cir. 1977), cert. denied, 434 U.S. 1012 (1978); United States v. Pilla, 550 F.2d 1085, 1093 (8th Cir.), cert. denied, 432 U.S. 907 (1977); United States v. Grismore, 546 F.2d 844, 847 (10th Cir. 1976); United States v. Whitesel, 543 F.2d 1176, 1177-80 (6th Cir. 1976), cert. denied, 431 U.S. 967 (1977); United States v. Kelley, 539 F.2d 1199, 1201-03 (9th Cir.), cert. denied, 429 U.S. 963 (1976); United States v. Jordan, 508 F.2d 750, 753 (7th Cir.), cert. denied, 423 U.S. 842 (1975); United States v. Cooper, 493 F.2d 473, 474 (5th Cir.), cert. denied, 419 U.S. 859 (1974); Turner v. American Bar Ass'n, 407 F. Supp. 451, 472-80 (N.D. Tex. 1975) (multi-district litigation) (Garza, J., sitting by designation), aff'd mem. sub nom. Taylor v. Montgomery, 539 F.2d 715 (7th Cir. 1976), also aff'd sub nom. Pilla v. American Bar Ass'n, 542 F.2d 56 (8th Cir. 1976); United States v. Stockheimer, 385 F. Supp. 979, 98385 (W.D. Wis. 1974), aff'd mem., 534 F.2d 331 (7th Cir.), cert. denied, 429 U.S. 966 (1976).

- See, e.g., United States v. Thibodeaux, No. 84-1869, slip op. at 3 (7th Cir. Feb. 20, 1985) (per curiam); Herrera-Venegas v. Sanchez-Rivera, 681 F.2d 41, 42 (1st Cir. 1982); United States v. Wilhelm, 570 F.2d 461, 465 (3d Cir. 1978); United States v. Taylor, 569 F.2d 448, 451 (7th Cir.), cert. denied, 435 U.S. 952 (1978); United States v. Irwin, 561 F.2d 198, 200 (10th Cir. 1977), cert. denied, 434 U.S. 1012 (1978); United States v. Pilla, 550 F.2d 1085, 1093 (8th Cir.), cert. denied, 432 U.S. 907 (1977); United States v. Grismore, 546 F.2d 844, 847 (10th Cir. 1976); United States v. Kelley, 539 F.2d 1199, 1203 (9th Cir.), cert. denied, 429 U.S. 963 (1976); United States v. Jordan, 508 F.2d 750, 753 (7th Cir.), cert. denied, 423 U.S. 842 (1975); United States v. Cooper, 493 F.2d 473, 474 (5th Cir.), cert. denied, 419 U.S. 859 (1974); Turner v. American Bar Ass'n, 407 F. Supp. 451, 478 (N.D. Tex. 1975) (multi-district litigation) (Garza, J., sitting by designation), aff'd mem. sub nom. Taylor v. Montgomery, 539 F.2d 715 (7th Cir. 1976), also aff'd sub nom. Pilla v. American Bar Ass'n, 542 F.2d 56 (8th Cir. 1976).

10 543 F.2d 1176 (6th Cir. 1976) (allowing accountant to sit at counsel table and advise defendant, but not to participate in the trial), cert. denied, 431 U.S. 967 (1977). In Whitesel, the Sixth Circuit relied upon both the history of the sixth amendment and Faretta in deciding that the framers of the sixth amendment "probabl[y] . . . did not mean to limit representation exclusively to "attorneys at law." "543 F.2d at 1179 . But the Whitesel court also concluded that the framers intended to give courts discretion to decide who could qualify as a representative. Id. The court stated that "at a minimum" the representative must be "sufficiently learned in the law" to represent his client adequately. Id. at 1180 . For a discussion of Whitesel, see 26 EMORY L.J. 457, 469 (1977).

11385 F. Supp. 979 (W.D. Wis. 1974) (holding that lay representative may be used if the choice is made knowingly and intelligently and if the representative is legally trained and qualified to act as an attorney; defendant permitted to be represented by former attorney whose license had been revoked), aff'd mem., 534 F.2d 331 (7th Cir.), cert. denied, 429 U.S. 966 (1976). While the Stockheimer court did not believe that the sixth amendment's 
which lay representation may, in the judge's discretion, be allowed.

This comment examines whether a criminal defendant has a constitutional right to lay representation and, if he does, the extent to which the government may regulate the exercise of that right. If the word "Counsel" in the sixth amendment includes lay representatives, such a right would be guaranteed expressly by the amendment. If not, the right might still implicitly be guaranteed by the structure of the sixth amendment, as is the right to selfrepresentation. Part I of this comment explores the meaning of "Counsel" in the sixth amendment and concludes that, although the use of lay counsel was common at the time the amendment was passed, the framers' intent in using this word is unclear. Part II considers the Supreme Court's holding in Faretta and shows that the same considerations of autonomy and dignity that support the right to proceed pro se also support an implicit, qualified sixth amendment right to lay representation; Part II then discusses society's interests in limiting representation to licensed attorneys and shows that they do not support a per se rule against the use of lay counsel. Part III examines the circumstances in which the defendant's right to control his own defense by using lay counsel may be limited by requirements that ensure the protection of overriding state interests in regulating the practice of law.

\section{The Meaning of "Counsel" in the Sixth Amendment}

The sixth amendment states, in relevant part, that "[i]n all criminal prosecutions, the accused shall enjoy the right ... to have the Assistance of Counsel for his defence." 12 Because the text of the amendment does not indicate whether the word "Counsel" was intended to include lay representatives, it is necessary to examine ancillary historical sources that might throw light on the meaning of the term.

Because the Judiciary Act of $1789^{13}$ was passed one day before the Bill of Rights was proposed, it has often been used to interpret the sixth amendment. ${ }^{14}$ Section 35 of the Act provided that: "in all

provision for "Counsel" includes only licensed attorneys, it still required that counsel be "legally trained," $385 \mathrm{~F}$. Supp. at 983, thus excluding most lay persons. Furthermore, the court concluded, as did the court in Whitesel, that it was within the judge's discretion to decide if a defendant should be allowed non-licensed counsel. Id.

12 U.S. Const. amend. VI.

13 Stat. 73 (1789).

14 See, e.g., Faretta v. California, 422 U.S. 806, 831 (1975); United States v. Wilhelm, 570 F.2d 461, 465 (3d Cir. 1978) ("Contemporaneous to the adoption of the Sixth Amendment and therefore reflective of its intended meaning, Congress enacted $\S 35$ of the Judici- 
the courts of the United States, the parties may plead and manage their own causes personally or by the assistance of such counsel or attorneys at law as by the rules of the said courts respectively shall be permitted to manage and conduct causes therein." 15 The statute might be read as employing the terms "counsel" and "attorneys at law" in the alternative, indicating that the framers understood "counsel" to mean something other than what would be the current equivalent of a licensed attorney. ${ }^{16}$ If this interpretation is correct, the right to counsel may not be limited to licensed attorneys. ${ }^{17}$ The phrase can also be read, however, to mean that a party might be assisted by either "counsel at law" or an "attorney at law." This latter reading is consistent with the notion that the language used by the framers was intended merely to reflect the British bifurcated system of barristers and solicitors, ${ }^{18}$ although such an argument is weakened by the fact that the British system had not survived long in the Colonies. ${ }^{19}$

ary Act of 1789 . . . ."); cf. Solina v. United States, 709 F.2d 160, 166 (2d Cir. 1983) (conceding "the value of an act of the First Congress as an aid in interpreting the Bill of Rights").

151 Stat. 73, 92 (1789) (emphasis added) (codified as amended at 28 U.S.C. $\S 1654$ (1982) (providing only for conduct of cases "personally or by counsel")).

${ }^{16}$ A statute passed in Congress's second session provided that "every person . . . accused and indicted for [treason or other capital offenses] shall also be allowed and admitted to make his full defence by counsel learned in the law." Act of Apr. 30, 1790, ch. IX, § 29, 1 Stat. 112, 118 (1790) (emphasis added). This evidence further indicates that Congress recognized a difference between counsel simpliciter and counsel "learned in the law" and intended to create different results in different statutes.

17 See United States v. Whitesel, 543 F.2d 1176, 1179 (6th Cir. 1976) ("[S]ince in the statute the terms 'counsel or attorneys at law' are employed alternatively, it seems probable that the proposers of the Sixth Amendment did not mean to limit representation exclusively to 'attorneys at law.' "), cert. denied, 431 U.S. 967 (1977).

18 See Solina v. United States, 709 F.2d 160, 166 (2d Cir. 1983) ("[T]he alternative phraseology used in $\S 35$ of the Act of 1789 stems from the English origins of the American legal profession and does not support the unusual interpretation advanced in Whitesel.").

10 See Lawrence Friedman, A History of American Law 275 (1973) ("The English distinctions of grade-between attorneys, counselors, barristers, and sergeants-exerted a certain fascination, but failed to leave a permanent mark on the "American bar."). It might also be argued that if the Judiciary Act and the sixth amendment were considered within one day of each other, inclusion of an item in one and omission in the other is clear evidence that the two were not intended to have the same meaning. Cf. Faretta v. California, 422 U.S. 806, 844 (1975) (Burger, C.J., dissenting) ("[U]nder traditional canons of construction, inclusion of the right [to self-representation] in the Judiciary Act and its omission from the constitutional amendment drafted at the same time by many of the same men, supports the conclusion that the omission was intentional.") (emphasis in original). This argument could lead to either of two results. First, if "counsel" in the Judiciary Act means a lay representative, then the sixth amendment's guarantee goes no further, since it contains only the term "Counsel" and not "attorney at law." This result is inconsistent, however, with the Supreme Court's interpretation of the sixth amendment as embodying the essential right to have a lawyer's assistance. See, e.g., Gideon v. Wainwright, 372 U.S. 335, 344 (1963) (citing "wide- 
Historical practice suggests that, contrary to modern-day notions, the framers thought of "counsel" as including lay persons. ${ }^{20}$ The first lawyers were personal friends of the litigant, brought into court by him so that he might take "counsel" with them before pleading. ${ }^{21}$ Indeed, lay representation was common in the Colonies, ${ }^{22}$ and some early statutes explicitly provided for lay representation. For example, the Massachusetts Body of Liberties provided that a defendant could employ "any man ... [p]rovided he give him noe fee or reward for his paines." ${ }^{\text {"23 }}$ The Pennsylvania Frame of Government, "perhaps 'the most influential of the Colonial documents protecting individual rights," "24 provided that " all per-

spread belief that lawyers in criminal courts are necessities, not luxuries"). Second, if "Counsel" in the sixth amendment means a licensed attorney, then the framers, by using a different formulation in the Judiciary Act, may have meant the Act, but only the Act, to grant a right to lay representation. If this is correct, there is no constitutional right to lay representation. A similar line of reasoning, however, implicitly was rejected in Faretta. The dissent argued that because the Judiciary Act expressly gave defendants the right to represent themselves, the framers must not have intended the sixth amendment to include that right or they would have written it into the amendment. Faretta, 422 U.S. at 844 (Burger, C.J., dissenting). The majority implicitly rejected this argument by relying on the Judiciary Act as evidence that the framers did intend a constitutional right to self-representation. Id. at $812-13,831$.

${ }^{20}$ In Faretta, the Court looked not only to "the structure of the Sixth Amendment" but also to "the English and colonial jurisprudence from which the Amendment emerged." 422 U.S. at 818.

${ }^{21} 1$ F. Pollock \& F. Maitland, The History of English Law 211-13 (2d ed. 1911). One scholar examined the origins of the word "attorney" and found that it came from "attornastis," which means "deputed," or to send another in your place. Herman CoHEN, HisTORY OF THE ENGLish BAR AND Attornatus to 1450, at 126 (1929). The attorney began in the thirteenth century as a simple messenger: "Any friend could go for you to the court, if, for instance, you were ill, . . . or take a message or an excuse . . . "Id. at 133-34; see also L. Friedman, supra note 19, at 81 ("The 'attorneys' of early Virginia records were not trained lawyers, but attorneys-in-fact, laymen helping their friends in court.").

${ }^{22}$ [T] he word "attorney," as used in early records of Colonial cases and statutes, did not imply necessarily a man bred to the law or who made its practise an exclusive employment. These "attorneys" were very largely traders, factors, land speculators and laymen of clever penmanship and easy volubility, whom parties employed to appear and talk for them in the courts.

Charles Warren, A History of the American Bar 4-5 (1911). Moreover, "[i]n all the Colonies, the courts were composed of laymen, with the possible exception of the Chief Justice." Id. at 3. And even in England, the barristers and solicitors were not distinguished by their education. At the Inns of Court in England, "[a]ny student who had eaten the prescribed number of dinners and paid his fees was made a counsellor at law; the ceremony was conducted like the return of stolen goods "without any questions being asked;" he need never have read a single page of any law book." "Id. at 152 (quoting W.B. ODGERS, A Century of LAW REForM ch. 1 (1901)).

${ }^{23}$ Faretta, 422 U.S. at 827 n.32 (quoting Massachusetts Body of Liberties art. 26 (1641)). This work compiled 100 fundamental laws, and is often called the first American law book. See C. WARREN, supra note 22 , at 64 .

24 Faretta, 422 U.S. at 828 n.37 (quoting 1 Bernard Schwartz, The Bill of Rights: A 
sons of all persuasions may freely appear in their own way . . . or, if unable, by their friends." "25 By the time of Independence, widespread approval of the use of professional attorneys had not yet developed. As the Supreme Court noted in Faretta: "The years of Revolution and Confederation saw an upsurge of antilawyer sentiment, a 'sudden revival, after the War of the Revolution, of the old dislike and distrust of lawyers as a class.' In the heat of these sentiments the Constitution was forged." 26 Indeed, licensing restrictions did not become common until nearly 100 years after the nation was founded. ${ }^{27}$

Even if the framers did not intend to restrict the sixth amendment to licensed counsel, the qualification in the Judiciary Act (that the assistance be from those who "by the rules of said courts ... shall be permitted to manage and conduct causes therein") indicates that the framers apparently intended that the courts should have some power to decide who practiced before them. ${ }^{28}$ Since lay representation was recognized at the time the sixth

\section{Documentary History 130 (1971)).}

${ }^{25}$ C. WARrEN, supra note 22, at 106 (quoting Pennsylvania Frame of Government). "During the first twenty years, there were probably not more than three or four trained English lawyers in the whole Province, although there were twenty-three persons called attorneys whose names are extant. These were, however, almost entirely laymen, with no legal education." Id. at 107.

26422 U.S. at 827 (footnote omitted) (quoting C. WARREN, supra note 22, at 212).

${ }^{27}$ Not until 1892, 14 years after its founding, did the American Bar Association (ABA) even recommend two years of law study (either in a law office or in law school); by 1908, the ABA was "expressing the hope that two years of college would soon be required before law school"; as late as 1917, no state required attendance at a law school. Stevens, Two Cheers for 1870: The American Law School, in LAw IN AMERICAN Hrstory 403, 493-504 (D. Fleming \& B. Bailyn eds. 1971).

Most licensing legislation actually came about through the efforts of a strong pressure group: the legal profession. James W. Hurst, The Growth of American Law 250, 277-79 (1950). The ABA's strong opposition to unauthorized practice did not begin until 1930, "a period of economic depression when lawyers, along with almost everyone else, were struggling to protect their livelihood from competition and economic catastrophe." Weckstein, Limitations on the Right to Counsel: The Unauthorized Practice of Law, 1978 UTAH L. REv. 649, 674. Later, "[a]ll States required that applicants to the Bar must meet some minimal standards, although the standards were not at all uniform. Some States had stringent standards of admission, whereas other States eventually eliminated all requirements for admission to the Bar, except good moral character." Turner v. American Bar Ass'n, 407 F. Supp. 451, 474 (N.D. Tex. 1975) (multi-district litigation) (Garza, J., sitting by designation), aff'd mem. sub nom. Taylor v. Montgomery, 539 F.2d 715 (7th Cir. 1976), also aff'd sub nom. Pilla v. American Bar Ass'n, 542 F.2d 56 (8th Cir. 1976).

${ }^{28}$ See supra text accompanying note 15 . "Perhaps the strongest conclusion which can be derived from the English development in its entirety and from early American practices is that the courts and not the legislators had within their hands the capacity and the power to shape the right to counsel into whatever mold seemed best." William BEANEY, THE Right to CoUnSEl in AMERICAN Courts 24 n.20 (1965). 
amendment was proposed, it is unlikely that the framers expected the courts to ban non-licensed counsel altogether. But the framers may have expected that courts would adapt their regulations to the changing judicial system; today's complicated evidentiary rules and abundance of licensed attorneys may justify increased control by courts.

Thus, while the framers of the sixth amendment may have expected that "counsel" would include lay representatives, the evidence is inconclusive. Furthermore, it is clear that the right to counsel of any kind was intended to be subject to regulation by the courts. Consequently, the available historical evidence about the framers' intent does not clearly support the notion of an explicit sixth amendment right to lay "counsel." If a right to lay representation is to be recognized, it must be inferred from the structure as well as the history of the sixth amendment.

\section{The Defendant's Right to Control His Defense}

As a common-sense matter, it would seem that the criminal defendant, who suffers the consequences of a guilty verdict, should be allowed ultimate control over the manner in which his defense is presented. This notion is reflected, for example, in the defendant's rights to notice, ${ }^{29}$ compulsory process, ${ }^{30}$ confrontation, ${ }^{31}$ and the right to be present at his trial, ${ }^{32}$ all of which are treated as personal rights of the defendant. Of course, the government's interest in maintaining an orderly and efficient judicial system may conflict with the defendant's right to control his defense, ${ }^{33}$ and a balance between the two must be established. In Faretta $v$. Cali-

29 U.S. Const. amend. VI ("the accused shall enjoy the right . . . to be informed of the nature and cause of the accusation"); see In re Oliver, 333 U.S. 257, 273 (1948) ("A person's right to reasonable notice of a charge against him, and an opportunity to be heard in his defense . . . are basic in our system of jurisprudence.").

${ }^{30}$ U.S. ConST. amend. VI ("the accused shall enjoy the right . . . to have compulsory process for obtaining witnesses in his favor"); see Washington v. Texas, 388 U.S. 14, 19 (1967) (right to compulsory process applies against the states).

31 U.S. CoNST. amend. VI ("the accused shall enjoy the right . . . to be confronted with the witnesses against him"); see Pointer v. Texas, 380 U.S. 400, 406 (1965) (right to confrontation applies against the states).

${ }^{32}$ See Lewis v. United States, 146 U.S. 370, 372 (1892) ("A leading principle that pervades the entire law of criminal procedure is that, after indictment found, nothing shall be done in the absence of the prisoner.").

ss See, e.g., Illinois v. Allen, 397 U.S. 337, 343 (1970) (defendant may lose right to be present if, after warning from judge, he continues to misbehave); cf. McKaskle v. Wiggins, 104 S. Ct. 944, 954 (1984) ("A defendant's Sixth Amendment rights are not vioiated when a trial judge appoints standby counsel-even over the defendant's objection-to relieve the judge of the need to explain and enforce basic rules of courtroom protocol . . . ."). 
fornia ${ }^{34}$ the Court struck such a balance in holding that the defendant's implicit sixth amendment right to represent himself outweighed the state interests. Faretta's rationale both supports the right to choose lay counsel and helps to determine the extent to which the government may restrict the exercise of this right in order to promote its own legitimate interests.

\section{A. Faretta and the Right to Self-Representation}

In Faretta, the defendant sought to represent himself at his trial for grand theft. Faretta did not want to be represented by the court-appointed attorney because he thought that the public defender's office was carrying too heavy a case load..$^{35}$ At first, the trial judge reluctantly granted Faretta's motion, ${ }^{36}$ but later, after questioning Faretta about the hearsay rule and state law governing challenges of potential jurors, the judge reversed this decision and ruled that Faretta had no state or federal constitutional right to represent himself. ${ }^{37}$ A public defender was subsequently appointed; following a trial, Faretta was convicted..$^{38}$

The Supreme Court held that Faretta had a constitutional right to represent himself. The Court reasoned that the sixth amendment's provisions for notice, confrontation, and compulsory process, when taken together, grant the defendant the right personally to "make his defense." 39 The Court also reasoned that the defendant should be free to make this choice because he is the one who will suffer the consequences if the defense fails. ${ }^{40}$ Consequently, the right to self-representation was held to be "necessarily implied by the structure of the [Sixth] Amendment."41 This implied right is not merely an extension of the right to waive assistance of counsel, but instead is an independent right based on the

34422 U.S. 806 (1975).

3s Id. at 807 .

36 Id. at 808 .

37 Id. at $808-10$.

3s Id. at 811. The California Court of Appeal affirmed the trial judge's ruling that Faretta had no constitutional right to represent himself, and the California Supreme Court denied review. See id. at 811-12.

30 The Sixth Amendment does not provide merely that a defense shall be made for the accused; it grants to the accused personally the right to make his defense. It is the accused, not counsel, who must be "informed of the nature and cause of the accusation," who must be "confronted with the witnesses against him," and who must be accorded "compulsory process for obtaining witnesses in his favor."

Id. at 819.

to Id. at 819-20.

41 Id. at 819 (footnote omitted). 
structure and history of the sixth amendment. ${ }^{42}$

The right to counsel supplements this scheme by guaranteeing that the defendant will have the aid of an assistant if, but only if, the defendant wants one. ${ }^{43}$ Counsel does have the power to make certain binding decisions about trial strategy, but this restriction on the defendant's right to control his defense "can only be justified . . . by the defendant's consent, at the outset, to accept counsel as his representative." ${ }^{44}$ If, on the other hand, the attorney is "unwanted," then "the defense presented is not the defense guaranteed [the defendant] by the Constitution, for, in a very real sense, it is not his defense." 45

The Court also noted that its reading of the sixth amendment was reinforced by historical practices in England ${ }^{46}$ and the American colonies. ${ }^{47}$ The colonists, for example, harbored deep distrust of lawyers, ${ }^{48}$ and many early state charters secured the right to self-representation. ${ }^{49}$

The Faretta Court recognized that its holding seemed contrary to previous decisions clearly indicating that the assistance of a lawyer is essential to a fair trial. ${ }^{50}$ Moreover, as the dissenters pointed out, the interest in a fair trial extends beyond the immediate defendant; society has an interest in seeing that justice is done and that the integrity of and public confidence in the legal system. are preserved. ${ }^{51}$ But the Court pointed out that the defendant will bear the brunt of any mistakes and may believe that the legal system is contriving against him if it forces an attorney upon him. ${ }^{\mathbf{6 2}}$

42 Id. at 819 n.15 (" '[T]he ability to waive a constitutional right does not ordinarily carry with it the right to insist upon the opposite of that right.' . . . [A]n implied right must arise independently from the design and history of the constitutional text ....") (quoting Singer v. United States, 380 U.S. 24, 34-35 (1965)).

43 Faretta, 422 U.S. at 820.

14 Id. at $820-21$.

45 Id. at 821 (emphasis in original).

18 Id. at 821-26.

17 Id. at $826-32$.

18 Id. at 826-27; see supra text accompanying note 26 .

49 Faretta, 422 U.S. at 828-32.

Bo Id. at 832-33; see cases cited supra note 3.

${ }^{61}$ See Faretta, 422 U.S. at 839 (Burger, C.J., dissenting); id. at 849 (Blackmun, J., dissenting).

${ }^{52}$ Id. at 833-34 (majority opinion) (" $[\mathrm{I}] \mathrm{t}$ is one thing to hold that every defendant, rich or poor, has the right to the assistance of counsel, and quite another to say that a State may compel a defendant to accept a lawyer he does not want."). Many defendants apparently fear that their court-appointed attorney is actually an agent of the state. See, e.g., Bazelon, The Realities of Gideon and Argersinger, NAT'L Legal AID \& Defender A. Briefcase, Jan. 1976, at 57, 59 ("Clients of public defenders feel they are essentially standing alone, without advice, at least advice that they can rely upon, because they believe their lawyers, and more 
Though the defendant's choice to proceed pro se will in most cases lead to a less effective defense, "his choice must be honored out of 'that respect for the individual which is the lifeblood of the law." ",53

Finally, the Court noted that, because the defendant would effectively be giving up many of the benefits of representation by a licensed attorney, the decision to represent himself must be made " 'knowingly and intelligently.' "54 Once this decision is made, the defendant must comply with all relevant procedural and substantive rules. ${ }^{.5}$ Moreover, the defendant would be foreclosed from claiming on appeal that he was denied "effective assistance of counsel." "56 The trial judge may, even over the defendant's objections, appoint standby counsel to aid the defendant upon request and to represent the defendant "in the event that termination of the defendant's self-representation is necessary."

The Supreme Court recently expanded on its discussion of the right to self-representation in McKaskle $v$. Wiggins, ${ }^{58}$ which involved a claim that standby counsel's unsolicited participation interfered with the defendant's ability to present his own defense. ${ }^{59}$ The Court ruled that Faretta does not require an absolute bar on participation by standby counsel but requires only that the defendant retain full control over his defense and that the jury must realize that the defendant is representing himself." "The right to

precisely, their public defenders, are not on their side."). For example, in In re Michael C., 21 Cal. 3d 471, 146 Cal. Rptr. 358, 579 P.2d 7 (1978), rev'd sub nom. Fare v. Michael C., 442 U.S. 707 (1979), an offer of an appointed attorney was met with the reply: "How I know you guys won't pull no police officer in and tell me he's an attorney?" $21 \mathrm{Cal}$. 3d at 474, $146 \mathrm{Cal}$. Rptr. at 359,579 P.2d at 8.

s3 422 U.S. at 834 (quoting Illinois v. Allen, 397 U.S. 337, 350-51 (1970)).

s4 422 U.S. at 835 (quoting Johnson v. Zerbst, 304 U.S. 458, 464-65 (1938)).

ss 422 U.S. at 834 n.46.

se Id.

s7 Id. (citation omitted). Circumstances that would make "termination of the defendant's self-representation . . . necessary" include serious and obstructive misconduct by the defendant. Id. (citing Illinois v. Allen, 397 U.S. 337 (1970)).

ss 104 S. Ct. 944 (1984).

so Id. at 947-50.

${ }^{\circ} I d$. at 950-51; see also id. at 950 ("[T] he primary focus must be on whether the defendant had a fair chance to present his case in his own way."). The Court found on the facts of the case that standby counsel's actions did not interfere with the defendant's ability to control his defense. All tactical decisions were made by the defendant, id. at 952-53, and to the extent that the defendant's pro se efforts were undermined, it was primarily because the defendant had invited or agreed to participation by counsel, id. at 953-54. Furthermore, the Court noted that a defendant's pro se rights are not infringed merely because counsel assists the defendant in handling "routine procedural or evidentiary" issues. Id. at 954. The Court did state, however, that there are instances in which "the defendant may legitimately claim that excessive involvement by counsel . . . may erode the dignitary values that the 
appear pro se exists to affirm the dignity and autonomy of the accused and to allow the presentation of what may, at least occasionally, be the accused's best possible defense." ${ }^{61}$ The "core" of this right is the defendant's "actual control over the case he chooses to present to the jury."62

\section{B. Faretta and the Right to Lay Representation}

Faretta established that the defendant has an affirmative right, implicit in the sixth amendment, to control his defense by proceeding pro se. The only difference between Faretta and the lay-representation case is that, instead of appearing pro se, the defendant in the latter case chooses a third party to act in his stead.

The interests in dignity and autonomy that support the defendant's right to appear pro se also support the right of a defendant to the assistance of lay counsel. A defendant may feel just as strongly about having a lay third party represent him as he does about representing himself. ${ }^{63}$ Similarly, the denial of lay representation may make the defendant feel just as oppressed by the legal system as does the denial of self representation. ${ }^{64}$ In both situations, licensed counsel is unwanted and possibly not trusted. ${ }^{65}$

If the result in Faretta had depended on the defendant's spe-

right to self-representation is intended to promote." Id. at 953.

${ }^{61}$ Id. at 950.

${ }^{62}$ Id. at 951.

${ }^{83}$ In United States v. Wilhelm, 570 F.2d 461 (3d Cir. 1978), for example, the defendant attached to his request for lay counsel affidavits stating that: his "religious convictions and conscience forbid [him] from seeking or receiving assistance or representation from any socalled licensed attorney or any other officer of the court"; that he "is personally incompetent to effectuate a good defense in [his] own behalf"; and that he "has confidence in [his] counsel of notice." Id. at 463.

B4 One problem that plagues the court system is that of overworked public defenders. Judge Bazelon summarized the findings of a National Legal Aid and Defender Association survey: "Public defenders . . . feel . . . compelled to accept case loads that they view and they know are unmanageable. . . . [W]itnesses are interviewed only in the corridors of court houses; legal research is done by flipping through the penal code during recesses. . . . There is not even adequate opportunity to consult fully with clients." Bazelon, supra note 52, at 58-59; see also Cooper v. Fitzharris, 551 F.2d 1162, 1163 n.1 (9th Cir. 1977) (district court found that counsel's failure to challenge improperly obtained evidence was due to "an overwhelmingly heavy caseload carried by Deputy Public Defenders at that time, which allowed counsel very little time for the preparation of each case" "), modified, 586 F.2d 1325 (9th Cir. 1978) (en banc), cert. denied, 440 U.S. 974 (1979); Wilson, Empty Handed Justice, JUDGES J., Winter 1983, at 21, 21-22 (citing evidence that the problem of overworked and underpaid public defenders is widespread). In such cases, the defendant's interests may in fact be better safeguarded by a lay representative, who can carefully attend to the defendant's case, than by a public defender.

${ }^{65}$ See supra note 52 and accompanying text. 
cial interest in speaking for himself, then the reasoning in that case would not support a right to lay representation. But Faretta's rationale, including the gloss Wiggins places on it, does not depend on the defendant's interest in speaking. The Court did not, for example, hold that a defendant must have a licensed attorney but should be allowed to speak to the judge and jury whenever he wants. Instead, the Court relied more generally on rights guaranteed by the sixth amendment that allow the defendant to participate in the making of "his defense" and the important interest in giving the defendant freedom of choice in deciding how he will present that defense. The central issue, as Wiggins emphasizes, is control over the strategic and tactical decisions that the defendant's case comprises. ${ }^{66}$

Furthermore, the Court in Faretta also relied on the fact that courts in England and in the American colonies allowed a defendant to represent himself. ${ }^{67}$ Because historical practice included lay representation as well, ${ }^{68}$ it supports the conclusion that the right to lay representation is implicit in the structure and history of the sixth amendment.

In general, Faretta established that the government may not force counsel on an unwilling defendant, but instead must allow the accused to make his own defense. Having recognized that the defendant's right to control his case includes the right to represent himself, it becomes difficult to distinguish the defendant's similar interest in controlling his case by allowing a lay third party to speak in his stead. If the government interest in limiting representation to licensed counsel does not override this right, defendants should be allowed the assistance of laymen at trial.

\section{Society's Interests}

As in Faretta, the next question in the lay-representation case is whether the defendant's right is outweighed by legitimate societal interests. Two such interests-accuracy of outcome and the efficient administration of justice-were addressed in Faretta. In the lay-representation context, a third interest must also be considered: the government interest in regulating the practice of law. All three of these interests have been relied upon by courts that have 819-20.

so See McKaskle v. Wiggins, 104 S. Ct. 944, 949-50 (1984); see also Faretta, 422 U.S. at

-7 See Faretta, 422 U.S. at 821-32; supra notes 46-49 and accompanying text.

-8 See supra notes 20-26 and accompanying text. 
denied a defendant's request for lay representation. ${ }^{69}$

1. Accuracy of Outcome. In the American criminal justice system, which employs the principle that the accused is presumed innocent until proven guilty, ${ }^{70}$ the government properly is concerned not only with obtaining convictions but also with ensuring that the innocent go free. ${ }^{71}$ Both self-representation and the use of non-licensed counsel will usually increase the chances of unjust conviction: defendants and non-licensed counsel are typically less experienced at conducting a defense than a licensed attorney and are less familiar with the rules of evidence and procedure. ${ }^{72}$ Nevertheless, the Faretta Court found society's interest in just verdicts to be outweighed by the defendant's right to control his own destiny. ${ }^{73}$

Moreover, although lay representation may decrease accuracy in comparison with licensed counsel, it is likely to increase accuracy in comparison with self-representation. The defendant, who has a strong interest in assuring that he has competent counsel, can be expected to choose a lay representative who is a more effective advocate than himself. ${ }^{74}$ Therefore, accuracy may in fact be

${ }^{69}$ See, e.g., Herrera-Venegas v. Sanchez-Rivera, 681 F.2d 41, 42 (1st Cir. 1982) (lack of remedies and sanctions against non-lawyer is "[o]ne of many good reasons" to deny lay representation); United States v. Wilhelm, 570 F.2d 461, 463 n.4 (3d Cir. 1978) (allowing lay counsel would produce "chaos in the courts") (quoting transcript of trial court proceedings); United States v. Kelley, 539 F.2d 1199, 1202 (9th Cir.) (allowing lay counsel "runs counter to the competing institutional interest in seeing that justice is administered fairly and efficiently"), cert. denied, 429 U.S. 963 (1976).

${ }^{70}$ See, e.g., Bell v. Wolfish, 441 U.S. 520,533 (1979) ("The principle that there is a presumption of innocence in favor of the accused is the undoubted law, axiomatic and elementary, and its enforcement lies at the foundation of the administration of our criminal law.' ") (quoting Coffin v. United States, 156 U.S. 432, 453 (1895)); cf., e.g., In re Winship, 397 U.S. 358,364 (1970) (the government must in a criminal case prove guilt beyond a reasonable doubt).

${ }^{71}$ See, e.g., Berger v. United States, 295 U.S. 78, 88 (1935) ("[The interest of the state] in a criminal prosecution is not that it shall win a case, but that justice shall be done."). For this reason, the courts may be willing to tolerate a certain number of erroneous acquittals in criminal cases, in order to decrease the chance that an innocent person will be convicted. W. La Fave \& A. Scott, Handbook on Criminal Law $\S 4$, at 15 (1972); see also President's Comm'n on Law Enforcement and Administration of Justice, The Challenge of Crime in a Free Society 7-12 (1967), reprinted in Stephen Saltzburg, American Criminal ProceDURE 24-29 (2d ed. 1984).

${ }^{2}$ See, e.g., Powell v. Alabama, 287 U.S. 45, 69 (1932) ("Even the intelligent and educated layman has small and sometimes no skill in the science of law. . . . Without [the help of counsel], though he be not guilty, he faces the danger of conviction because he does not know how to establish his innocence."); Faretta, 422 U.S. at 838-40 (Burger, C.J., dissenting).

${ }^{73}$ See Faretta, 422 U.S. at 832-34.

${ }^{4}$ Cf., e.g., Gideon v. Wainwright, 372 U.S. 335, 344 (1963) ("[T] $]$ here are few defendants charged with crime . . . who fail to hire the best lawyers they can get . . . ."). 
increased in those cases where the defendant, if prevented from choosing a lay representative, would instead appear pro se..$^{75}$

2. Efficient Administration of Justice. Because of the intricacies of modern trial practice and procedure, the participation of laymen in the conduct of criminal trials inevitably impairs the efficiency of the criminal justice system. ${ }^{76}$ Furthermore, because the Speedy Trial Act ${ }^{77}$ gives priority to criminal trials, any delay in the progress of those trials necessarily creates delay in civil trials waiting on the docket. ${ }^{78}$ There already is much concern over congestion in the courts, ${ }^{79}$ and one court has expressed the concern that allowing lay counsel would create " 'chaos in the courts" "'Bo and "profoundly alter the legal framework in which criminal proceedings are scrupulously conducted."

The same argument, however, can be made against the right to self-representation. ${ }^{82}$ Although it is likely that a criminal defendant will take longer to present his defense and will need more assistance from the trial judge than would an attorney, the Court in F'aretta did not limit the right of self-representation to those

7s Conversely, the interest in accuracy is impaired in those cases where the defendant chooses a lay representative but would otherwise have accepted licensed counsel. In these cases, however, this interest is counterbalanced by the defendant's interest in conducting his own defense.

${ }^{76}$ See Faretta, 422 U.S. at 845 (Burger, C.J., dissenting) (if there is "widespread exercise of the . . . constitutional right to self-representation, . . . there will be added congestion in the courts and . . . the quality of justice will suffer").

${ }^{27} 18$ U.S.C. $\$ \S 3161-3174$ (1982). The Act requires that an information or indictment be filed and the trial begin within specified time limits. Id. $\S 3161$.

78 See, e.g., Monek, Court Delay: Some Causes and Remedies, 1983 Trial Law. Guide 153, 155 (discussing how a congested criminal docket creates delays in the civil docket).

79 See, e.g., Hufstedler \& Nejelski, Reducing Court Costs and Delay: A Special Issue, JuDGES J., Spring 1981, at 2, 2 ("Many potential cases are not brought because of the relatively high costs of litigation and long delays-up to five years in some jurisdictions."); J.B. Jennings, Evaluation of the Manhattan Criminal Courts Master Calendar Project 111 (1972) ("Congestion and delay in the courts throughout the country threaten to strangle our system of justice . . . ."), quoted in Monek, supra note 78, at 155.

${ }^{80}$ United States v. Wilhelm, 570 F.2d 461, 463 n.4 (3d Cir. 1978) (quoting transcript of trial court proceedings).

s1 Id. at 465; see also United States v. Kelley, 539 F.2d 1199, 1202 (9th Cir.) (lay representation "runs counter to the competing institutional interest in seeing that justice is administered fairly and efficiently with the assistance of competent lawyers"), cert. denied, 429 U.S. 963 (1976); cf. Faretta, 422 U.S. at 845 (Burger, C.J., dissenting) (if there is widespread exercise of the right to self-representation, "there will be added congestion in the courts and . . . the quality of justice will suffer"). If the court in Wilhelm meant that chaos would result because laymen are not required to follow procedural rules, then the court's statement is misleading. Pro se defendants are required to conform to the rules of procedure and evidence, see Faretta, 422 U.S. at 834 n.46, and the same would hold true for nonlicensed counsel, see infra notes 94-106 and accompanying text.

${ }^{82}$ See Faretta, 422 U.S. at 845 (Burger, C.J., dissenting). 
defendants who could act as competently as a licensed attorney or who would not cause too great a delay. ${ }^{83}$ Faretta already has weighed the interest in judicial efficiency against the defendant's right to control his defense and has found that the latter prevails. ${ }^{84}$

3. Regulation of the Practice of Law. The states have a significant interest in regulating the practice of law. ${ }^{85}$ This interest includes establishing standards of minimum knowledge of law and moral fitness, and punishing unqualified individuals who attempt to practice law. ${ }^{86}$ In Turner $v$. American Bar Association, ${ }^{87}$ the dis-

${ }^{83}$ See id. at 836 ("We need make no assessment of how well or poorly Faretta had mastered the intricacies of the hearsay rule and the California code provisions that govern challenges of potential jurors on voir dire. For his technical legal knowledge, as such, was not relevant to an assessment of his knowing exercise of the right to defend himself.") (footnote omitted).

84 Of course, the unrestricted use of lay counsel of the defendant's choice might be extraordinarily disruptive. Faretta itself acknowledged that the right to self-representation could be overridden by the need to avoid undue disruption of trials. See id. at 834 n.46. This consideration would not, however, justify a per se rule against the use of lay counsel. Reasonable regulations, such as those suggested infra notes 94-106 and accompanying text, should be used to prevent this evil.

${ }^{\text {ss }}$ [T] $\mathrm{T}$ he States have a compelling interest in the practice of professions within their boundaries, and . . . as part of their power to protect the public health, safety, and other valid interests they have broad power to establish standards for licensing practitioners and regulating the practice of professions. . . The interest of the States in regulating lawyers is especially great since lawyers are essential to the primary governmental function of administering justice, and have historically been "officers of the courts."

Goldfarb v. Virginia State Bar, 421 U.S. 773, 792 (1975) (citations omitted) (holding, however, that state minimum-fee schedules are within the reach of the Sherman Act).

${ }^{86}$ Cf. Schware v. Board of Law Examiners, 353 U.S. 232, 239 (1957) ("[A]ny qualification must have a rational connection with the applicant's fitness or capacity to practice law."). The importance of this state interest has not always been as clear as it is now assumed to be. See, e.g., Rhode, Policing the Professional Monopoly: A Constitutional and Empirical Analysis of Unauthorized Practice Prohibitions, 34 Stan. L. Rev. 1, 6-7 (1981) ("[U]ntil the 1930s, the organized bar was largely insensible of the grave public danger unauthorized practice has since been thought to pose.") (footnote omitted); Stevens, supra note 27 , at 459 (in 1917, no state required attendance at a law school). There was a time when many states required no special qualifications, except perhaps good moral character. See, e.g., J. HuRST, supra note 27 , at 250 (Indiana's state constitution once "declared that '[e]very person of good moral character . . . shall be entitled . . . to practice law . . . ."). The ABA's opposition to unauthorized practice did not become forceful until 1930, "a period of economic depression when lawyers, along with almost everyone else, were struggling to protect their livelihood from competition and economic catastrophe." Weckstein, supra note 27 , at 674 (footnote omitted). There are those who believe that regulation of the legal profession serves primarily the legal profession's, not the public's, interests. See, e.g., Morgan, The Evolving Concept of Professional Responsibility, 90 Harv. L. Rev. 702, 707 (1977) ("Ostensibly designed to ensure that clients are served only by persons of integrity and competence, the unauthorized practice rules have historically been used to suppress competition by lay persons seeking to perform services at less cost than those provided by members of the Bar.") (footnote omitted); J. HuRST, supra note 27, at 323 ("[The] coincidence of events ill fitted claims that [unauthorized practice] activity was moved simply by regard for 
trict court rejected the defendant's request for lay representation on the ground that granting such a request "would amount to a wholesale authorization of the lay practice of law." 88

To the extent that this interest includes accuracy of outcome or efficiency of judicial administration, it merely involves the same interests that were at stake in Faretta, and the defendant's interest in controlling his own defense is overriding. ${ }^{89}$ But regulation of the legal profession is designed to serve an additional goal: it seeks to protect the consumer of legal services by assuring him that any lawyer he hires has met minimum standards of fitness. ${ }^{90}$ Furthermore, solicitation rules restrict the ability of attorneys to coerce potential clients. ${ }^{91}$

It is with respect to the state interest in protecting the public that lay representation clearly differs from self-representation. In the latter case, the defendant need only deal with himself; in the former, he must choose and work with a representative. Moreover, an individual is not likely to commit crimes merely for the purpose of representing himself; an aggressive lay counsel, however, may have an incentive to seek out accused individuals in order to develop a market for his services. It is certainly legitimate for the

protecting the public against the incompetent or unscrupulous.").

${ }_{87} 407$ F. Supp. 451 (N.D. Tex. 1975) (multi-district litigation) (Garza, J., sitting by designation), aff'd mem. sub nom. Taylor v. Montgomery, 539 F.2d 715 (7th Cir. 1976), also aff'd sub nom. Pilla v. American Bar Ass'n, 542 F.2d 56 (8th Cir. 1976).

407 F. Supp. at 478.

89 See supra text accompanying notes 73-84.

90 "The prohibition against the practice of law by a layman is grounded in the need of the public for integrity and competence of those who undertake to render legal services." Model Code of Professional Responsibility EC 3-1 (1980). A related state interest is "in preventing legally untrained shysters who pose as attorneys from milking the public for pecuniary gain." Hackin v. Arizona, 389 U.S. 143, $151-52$ (1967); see also Solina v. United States, 709 F.2d 160 (2d Cir. 1983) (defendant represented by an imposter was entitled to new trial despite insufficient evidence to show the representative incompetent and overwhelming evidence against the defendant); Harrison v. United States, 387 F.2d 203, 212 (D.C. Cir. 1967) (defendant's sixth amendment rights were violated when he was represented by a layman who was, without his knowledge, "masquerading as a qualified attorney"), rev'd on other grounds, 392 U.S. 219 (1968). The "poseur" case is, however, very different from the lay-representation case. In the former case, the defendant is under the misimpression that he is being represented by a licensed attorney, while in the latter he knowingly chooses not to be represented by a licensed attorney because he thinks that this course is in his best interest.

1 See, e.g., Ohralik v. Ohio State Bar Ass'n, 436 U.S. 447, 468 (1978) (upholding punishment of attorney who solicited accident victims). Solicitation rules may, however, yield to the exercise of constitutional rights. See, e.g., In re Primus, 436 U.S. 412, 434-35 (1978) (absent a showing of undue influence, overreaching, or misrepresentation, the Constitution protected solicitation, by letter, of women wrongfully sterilized); NAACP v. Button, 371 U.S. 415, 428-29 (1963) (upholding right to solicit prospective litigants for the purpose of furthering NAACP's civil rights objectives). 
states to be concerned about the growth of a market in lay counsel, with the attendant problems of inadequate legal services and coercion.

The state interest in regulating the practice of law rests principally on the need to protect the unwary or ignorant consumer of legal services from purchasing substandard or unwanted services. To require individual determinations in all instances-to see if non-licensed counsel is in fact unqualified or if in fact a client was coerced-would create an administrative nightmare. Accordingly, broad prophylactic rules regulating the practice of law over the full range of legal services are not only desirable, but are necessary to achieve the state's goals.

That this is true over the broad run of the practice of law, however, is insufficient to justify such an approach in the limited context of a criminal defendant's assertion of his constitutional right to lay representation. In this narrow sphere, individualized inquiries into the qualifications of lay counsel are feasible. The trial judge could examine the representative's qualifications and the defendant's knowledge about those qualifications before the representative could proceed in court. So long as the criminal defendant voluntarily chooses his lay representative, with full knowledge of the possible consequences, the state interests in protecting the ignorant consumer and preventing coercion are not threatened. And if appropriate safeguards are used, the state interests in preventing a market for lay services and the use of incompetent lay counsel also can be preserved.

The only state interest that could override a defendant's constitutional interest in the use of lay counsel, then, is administrative convenience. Such an interest is insufficient in this context for two reasons. First, requiring individualized determinations in the limited class of cases where a criminal defendant wishes to use lay counsel would create far fewer administrative problems than requiring such determinations in all cases of provision of legal services by laymen. Second, and more important, a gain in administrative convenience alone cannot override completely the defendant's sixth amendment interest in controlling his own defense by using a qualified lay counsel of his choice. "The power of the States to control the practice of law cannot be exercised so as to abrogate federally protected rights." ${ }^{22}$ Faretta itself also implic-

${ }_{92}$ Johnson v. Avery, 393 U.S. 483, 490 n.11 (1969) (holding that states may not absolutely bar prison inmates from providing legal assistance (in preparing habeas corpus petitions) to other prisoners). For this proposition, the Johnson Court cited NAACP v. Button, 
itly resolved this issue by declaring unconstitutional any per se rule against self-representation and by requiring that any regulation be restricted to those cases where countervailing interests actually are at stake..$^{93}$

\section{The Scope of Permissible Regulation}

Faretta indicates that the scope of permissible regulation of the defendant's right to control his defense must be narrow. In the self-representation situation, for example, a court may appoint standby counsel, even over the defendant's objection, but only so long as the defendant retains control over the case and so long as the presence of the standby counsel does not destroy the jury's perception that the defendant is representing himself. ${ }^{94}$ The same should be true in the lay-representation case-regulation should be narrowly tailored to ensure that the defendant's ability to choose a lay representative is interfered with only where it is actually necessary to serve some legitimate interest. As in the self-representation case, regulations that slightly interfere with the defendant's ability to control his defense should be allowed in order to serve overriding interests, such as the state's interest in regulation of the legal profession. But the general rule, in sharp contrast to the prevailing approach, should be that lay representation is permissible.

Because every criminal defendant has the right to a licensed attorney, ${ }^{95}$ when the defendant chooses to proceed instead with lay

371 U.S. 415, 438-44 (1963), where the Court held that state interests underlying anti-solicitation laws could not override constitutional rights affected by the NAACP's attempts to solicit potential plaintiffs to bring desegregation suits.

${ }^{93}$ A similar result was reached in United States v. Stockheimer, 385 F. Supp. 979 (W.D. Wis. 1974), aff'd mem., 534 F.2d 331 (7th Cir.), cert. denied, 429 U.S. 966 (1976), where nonlicensed attorneys were allowed to represent the defendant as long as their presence "d[id] not appear to threaten the orderly conduct of the trial." 385 F. Supp. at 985 ; see supra note 11 (discussing Stockheimer). The court relied on the defendant's ability to choose who would best represent him. Cf. Michigan v. Mosley, 423 U.S. 96, 108-09 (1975) (White, J., concurring in the result) ("Unless an individual is incompetent, we have in the past rejected any paternalistic rule protecting a defendant from his intelligent and voluntary decisions about his own criminal case."). The regulations suggested infra notes 94-106 and accompanying text go beyond those advocated in Stockheimer because the lay representative in that case was still subject to criminal sanctions for representing the defendant, see Stockheimer, 385 F. Supp. at 985 (noting that the court was not affording lay counsel any immunity from state unauthorized-practice laws); cf. United States v. Peterson, 550 F.2d 379, 385 (7th Cir. 1977) (apparently approving, in dictum, the Stockheimer court's no-immunity position), and the right itself was subject to the absolute discretion of the trial judge, with no presumptions whatsoever in favor of the defendant.

94 See McKaskle v. Wiggins, 104 S. Ct. 944, 954 (1984).

9s Johnson v. Zerbst, 304 U.S. 458, 463 (1938) (right to counsel in federal criminal proceedings); Gideon v. Wainwright, 372 U.S. 335,344 (1963) (right to counsel extended to 
representation, his waiver of the right to a licensed attorney must be "knowingly and intelligently" made, under the standard of Johnson $v$. Zerbst. ${ }^{96}$ The court must be satisfied that the defendant is aware of the possible detrimental consequences of his decision, ${ }^{97}$ and the court's determination should be made part of the record. ${ }^{88}$

The trial judge may also investigate the qualifications of the lay representative. The principal difference between the lay-representation and the self-representation cases is the existence of an agent in place of the defendant, and it is this fact alone that justifies the exercise of a greater degree of control in the lay-representation situation. ${ }^{99}$ Consequently, the investigation should focus on the relationship between the defendant and his representative, and the trial judge should deny the defendant's motion only where there is some apparent problem in the relationship. The following are examples of situations in which the trial judge would be justified in disqualifying a proposed lay representative.

First, since the primary concern is with ensuring that the defendant has knowingly and intelligently chosen the particular layman, the court should examine the relationship between the lay counsel and the defendant for evidence of undue influence or coercion; to this end, the current solicitation rules binding on members of the bar should be strictly enforced against lay counsel. ${ }^{100}$

Second, the lay counsel may properly be required to file an affidavit disclosing his education, experience, past criminal record, and any special relation to the litigant or to the subject matter of the suit. The purpose of this inquiry would be to satisfy the judge that the lay representative indeed possesses whatever qualities the defendant believed him to have when he was chosen. ${ }^{101}$

Third, in order to prevent the development of a market for lay

state criminal proceedings).

${ }^{96} 304$ U.S. 458, 464 (1938).

${ }^{87}$ Id. at 465; see also Faretta, 422 U.S. at 835.

${ }^{a 8}$ Weckstein, supra note 27 , at 676.

so See supra notes 90-94 and accompanying text.

${ }^{100}$ The concern is that a "fast-talking" lay counsel will persuade the defendant that he, the fast talker, can better represent the defendant than a licensed lawyer. Cf. Ohralik v. Ohio State Bar Ass'n, 436 U.S. 447, 461, 468 (1978) (the state may discipline a lawyer for soliciting clients in person for pecuniary gain under circumstances likely to pose dangers of overreaching). The state can protect its interests in the lay-representation context by imposing penalties on non-lawyers whose solicitation efforts pose the same dangers.

${ }^{102}$ Cf. Solina v. United States, 709 F.2d 160, 168-69 (2d Cir. 1983) (someone posing as a lawyer will not satisfy the sixth amendment's "Assistance of Counsel" requirement); supra note 90 (discussing "poseur" problem). 
counsel, the court should ensure that there will be no payment to the lay representative beyond an amount necessary to make up for lost income from regular employment. While there should be no monetary incentive for the lay representative to take on this responsibility, there should also be no disincentive, such as an uncompensated foregone salary. The court should also verify that the lay representative is not in the practice of representing criminal defendants in court-that he is not in fact a "professional lay representative" and does not hold himself out generally as having any special expertise in criminal-law advocacy.

Once lay counsel has been approved, the lay counsel's actions must be as binding on the defendant as if they had been made by the defendant himself in a self-representation case. ${ }^{102}$ If there is a difference of opinion concerning trial strategy, the defendant's choice should be binding, notwithstanding the fact that if he had chosen to have his defense presented by licensed counsel, the decisions of the counsel would have bound the defendant. ${ }^{103}$ This departure from the normal allocation of decisionmaking between attorney and client is justified by the fact that the lay representative has no special legal expertise; lay counsel is a surrogate for the defendant rather than for a licensed attorney. Furthermore, because the defendant has waived his right to licensed counsel, he should not be allowed to complain later that he has received ineffective assistance of counsel. ${ }^{104}$ Finally, the defendant could lose the right to lay representation if the right is abused-for example, where the lay representative engages in disruptive conduct-just as an abu-

${ }^{102}$ See Faretta, 422 U.S. at 834 n.46. In a compromise solution, the First Circuit allowed the "assistance" of a "jailhouse lawyer" but denied "representation." Herrera-Venegas v. Sanchez-Rivera, 681 F.2d 41, 42 (1st Cir. 1982). The court stated that when defendants are not represented by licensed counsel, "they must take legal responsibility for, and must themselves sign all papers filed in this court relative to their own case . . . . Id. This result is consistent with the suggestion in text, see infra text accompanying note 103, that the defendant be the one to make all final decisions when there is a disagreement over trial strategy.

${ }^{103}$ See Faretta, 422 U.S. at 820.

10 Cf. id. at $834 \mathrm{n.46}$ ("[A] defendant who elects to represent himself cannot thereafter complain that the quality of his own defense amounted to a denial of 'effective assistance of counsel.'"). Furthermore, when a defendant elects to be represented by non-licensed counsel, he is not bargaining for a qualified lawyer and thus there can be no implied breach of warranty with respect to quality of services. But see Biakanja v. Irving, 49 Cal 2d. 647, 320 P.2d 16 (1958) (notary public who engaged in the unauthorized practice of law by preparing a will that was subsequently found to be invalid was liable to the beneficiary for the resulting damage sustained); Latson v. Eaton, 341 P.2d 247, 248 (Okla. 1959) (non-lawyer liable for improper preparation of legal documents for hire). 
sive defendant may lose the right to be present at his trial ${ }^{105}$ or to proceed pro se. ${ }^{106}$

\section{Conclusion}

No court has yet recognized a constitutional right to lay representation. Although the language of the sixth amendment is inconclusive, it is clear that in the eighteenth century the word "counsel" did not always mean a licensed attorney. Indeed, lay representation was common in the American colonies. The Supreme Court's decision in Faretta v. California, upholding the defendant's right to appear pro se, stands more generally for the proposition that a defendant has a right, implicit in the sixth amendment, to control his own defense. The rationale of Faretta logically extends to defendants who wish to have lay representation. A criminal defendant's right to lay counsel should be recognized, subject to court supervision that would preserve important state interests in the regulation of the legal profession.

Mindy D. Block 